Smetannikov, A., Fomin, D., Tsema, L., Shishkov, D., Korlyakov, K., Osonov, D., Vasbieva, M., Yamaltdinova, $V$., Novikova, $T$ (2020): The influence of unconventional mineral fertilizers based on the processing of $K$ - $M g$ ores on yield and quality of seed potato, as well as soil fertility parameters. Agriculture and Forestry, 66 (4): $29-43$.

DOI: 10.17707/AgricultForest.66.4.03

Andrey SMETANNIKOV ${ }^{1}$, Denis FOMIN ${ }^{2}$, Lubov' TSEMA', Danil SHISHKOV', Konstantin KORLYAKOV ${ }^{2 *}$, Dmitry ONOSOV ${ }^{1}$, Marina VASBIEVA ${ }^{2}$, Venera YAMALTDINOVA ${ }^{2}$,Tat'yana NOVIKOVA ${ }^{2}$

\title{
THE INFLUENCE OF UNCONVENTIONAL MINERAL FERTILIZERS BASED ON THE PROCESSING OF K-MG ORES ON YIELD AND QUALITY OF SEED POTATO, AS WELL AS SOIL FERTILITY PARAMETERS
}

\begin{abstract}
SUMMARY
The results of the field study with traditional mineral fertilizers and unconventional one, based on the processing of $\mathrm{K}-\mathrm{Mg}$ ores, on seed potato planting are presented in this paper. The efficiency and aftereffect of potassium fertilizers ( $\mathrm{KCl}$ and the processing product from clay-salt sludge) on the NP background were studied. The technology for the production of new fertilizer from clay-salt waste (sludge) remaining as a result of potassium fertilizers production from natural $\mathrm{K}-\mathrm{Mg}$ ores, was elaborated in Mining Institute, the division of Perm Federal Research Center. The resulting product, containing K, $\mathrm{Ca}, \mathrm{Mg}$ and trace elements, which has the properties of fertilizer and ameliorant, has received the name the cinder of clay-salt sludge. The main processes in the technology are waste enrichment and subsequent high-temperature calcination of the enriched concentrate. As a result, the product, with the properties of multiple slow-release fertilizer was formed on a chloride-free basis. It is undesirable to use for potato fertilizers containing chlorine, so it is useful to expand the range of potassium fertilizers. The field trials with cinder were fulfilled on the experimental plots of Perm Agricultural Scientific Research Institute, the division of Perm Federal Research Center, in 2018-2020 years. The experimental scheme included treatments: control (without fertilizers), NP - background; $\mathrm{NP}+\mathrm{KCl}$ and $\mathrm{NP}+$ cinder. Potassium fertilizers were used in autumn (basic application) and in
\end{abstract}

\footnotetext{
${ }^{1}$ Andrey Smetannikov, Dmitry Onosov, Mining institute, the division of Perm Federal Research Center of the Ural Branch of the Russian Academy of Sciences, 614007, Sibirskaya St., 78A, Perm, RUSSIA;

${ }^{2}$ Denis Fomin, Lubov' Tsema, Danil Shishkov, Konstantin Korlyakov* (corresponding author: korlyakovkn@rambler.ru), Marina Vasbieva, Venera Yamaltdinova, Tat'yana Novikova, Perm Agricultural Research Institute, the division of Perm Federal Research Center of the Ural Branch of the Russian Academy of Sciences, 614532, Lobanovo, Perm region, RUSSIA;

Paper presented at the $11^{\text {th }}$ International Scientific Agricultural Symposium "AGROSYM 2020".

Notes: The authors declare that they have no conflicts of interest. Authorship Form signed online.

Recieved:11/10/2020

Accepted:25/11/2020
} 
spring (pre-planting application). No fertilizers were used in 2020. The influence of mineral fertilizers on yield and quality of seed potato, as well as soil fertility parameters were studied. The obtained results showed that the direct effect of unconventional fertilizer (cinder) with its pre-planting application was approximately equal to the effect of traditional potassium chloride fertilization, provided that the rates in the active substance were equal (yield in $2019-46.0$ and $47.1 \mathrm{t}^{-1}$ ha, respectively). The use of cinder did not have a significant effect on the quality indicators of potato tubers both directly in the year of fertilization and after the storage period. Cinder, in contrast to the standard $\mathrm{KCl}$ fertilizer, had a positive effect on the content of exchangeable potassium in the soil. Research with unconventional mineral fertilizers based on $\mathrm{K}-\mathrm{Mg}$ ore processing wastes should be continued with an emphasis on the study of long-term action as a complex ameliorant.

Keywords: Seed potato, mineral fertilizers, K-Mg ores, potassium, yield, soil fertility

\section{INTRODUCTION}

Potato (Solanum tuberosum L.) is one of the main food crops in the world. Total area occupied by potato in the world according to FAO, in 2015 was about 19 million hectares (FAOSTAT, 2015). The area occupied by potato in Russia, is about 2 million hectares. It is the first place in Europe and the second place in the world after China.

The total volume of world potato production in 2019 amounted to 376.8 million tons, in Russia - 29.8 million tons, it is third place in the world after China - 89 million tons and India - 45.3 million tons. At the same time, the average yield of this crop in the country, about $15 \mathrm{t} \mathrm{ha}^{-1}$, remains one of the lowest (Zhevora, et. al., 2019). The main reasons for this include the low quality of planting material, significant losses during the growing season as a result of damage by numerous pests and diseases, as well as due to high spread of weeds. The consequences of abiotic stresses, such as droughts, unfavorable physical and agrochemical properties of soils, and unbalanced mineral nutrition, make a significant contribution to the decrease of potential yields (Korshunov, et. al., 2003, Zhevora, et. al. 2017).

Potato does not tolerate acidic soils with low organic matter content. Most of the arable land in the Non-Black Earth Zone of Russia is occupied by acidic sod-podzolic soils. It is necessary to fulfill set of measures to increase their fertility, improve their agrochemical and agrophysical properties in order to use these soils for potato requirements.

The most important features of this culture include increased requirements for nutrients, especially potassium, as well as a long period of nutrition. The maximum input of nitrogen and phosphorus by plants usually occurs before flowering, while the supply of potassium continues until the full physiological maturity of tubers. Potassium stimulates the synthesis of sugars and high molecular weight carbohydrates - starch, cellulose, pectin substances, xylans, 
both in leaves and in potato tubers (Korshunov, et. al., 2003). The results of numerous studies prove that the greatest return from the use of nitrogen and phosphorus fertilizers can be achieved only on the background of a sufficient supply of potassium. This trend is well traced not only for crops that consume large amounts of potassium (potato, root crops), but also for cereals and forage crops (Mikhailova et. al., 2013, Rajičić V., et. al., 2019, Yamaltdinova V.R. et. al., 2019, Rajičić V., et. al., 2020).

Potato is responsive to fertilization, primarily potassium. The main type of potassium fertilizer used in agriculture is potassium chloride. However, for potato, it is undesirable to use fertilizers containing chlorine, since carbohydrate metabolism is disturbed under the influence of it during the formation of the crop. Therefore, it is necessary to expand the range of other forms of potash fertilizers.

Many researchers (Smetannikov et. al, 2017) consider that in some cases it is advisable to use complex fertilizers, which include macro- and microelements, as well as ameliorating minerals: dolomite, calcium carbonates and sulfates. Potato needs a neutral or slightly acidic soil, so the use of ameliorants has a positive effect on its productivity. Potato is often planted on peaty soils, where there is a lack of trace elements, primarily copper. Copper is also a part of many fungicides, therefore, a full supply of potato plants with copper can play a role in the prevention of fungal diseases. Potato plants also need other trace elements, the main of which are $\mathrm{Zn}, \mathrm{B}$, Mo. The use of complex fertilizers, which include macronutrients, as well as copper, iron, zinc, boron, molybdenum, according to Sharipova et. al. (2016), reduces the pesticide load on plants by 30 percent, increases yields by $15-30$ percent.

With the autumn application of fertilizers before fall plowing, nutrient losses often occur during the autumn-winter period, as well as during the spring period as a result of snow melting. Extremely large losses are observed in regions with a flushing water regime, as well as in the case of the use of water soluble fertilizers, for example, potassium chloride. In this connection, a search is being made for ways to reduce these losses. One of the methods is the use of fertilizers with reduced solubility (slow- release). Other ways to slow down the input of nutrients to the soil are granulation and encapsulation, but these techniques slow down dissolution to a small extent (Krutko and Shevchuk, 2011, Gurbanova et. al., 2017).

Sometimes, the products of sludge and chemical reagents sintering used as slow- release fertilizers (Hu et. al., 2018), as well as the product of the merlinoite synthesis $\left(\mathrm{K}_{5} \mathrm{Ca}_{2}\left(\mathrm{Si}_{23} \mathrm{~A}_{19}\right) \mathrm{O}_{64} \times 24 \mathrm{H}_{2} \mathrm{O}\right)$ from coal and other products ( $\mathrm{Li}$, et. al., 2014, Ruthrof, et. al., 2018).

An accompanying, but essential role play the possibility of waste disposal in the production of potassium fertilizers. One of the largest deposits of potassium, magnesium and sodium salts, located in Russia - Verhnekamskoe, contains a third of the world's reserves, which are mainly used for the potassium fertilizers production. This deposit is located in the north of Perm Region (Solikamsk). Mining wastes in interaction with natural and technogenic 
compounds form organic-mineral complexes that represent a great environmental hazard (Bachurin et. al., 2014). It is extremely important that the reserves of claysalt sludge in the sludge storage facilities of "Uralkaly" company amount more than 50 million tons. In addition, the annual output of sludge from six ore processing plants is more than two million tons (Onosov and Smetannikov, 2014).

Studies of waste products from the mining industry have shown that their complex utilization, in addition to environmental value, can bring significant profits. Sludge is a suspension, which contains 30 percent water-insoluble residue (hereinafter WIR), up to 30 percent residual $\mathrm{K}$ and $\mathrm{Na}$ chlorides, and about 40 percent $\mathrm{H}_{2} \mathrm{O}$. In turn, WIR contains the following minerals: quartz, potassium feldspar (FS) - a source of potassium; calcium sulfates (gypsum and anhydrite), dolomite, which are ameliorant minerals, then, sulfides $\mathrm{Cu}, \mathrm{Zn}$, etc., which can be positioned as micronutrient fertilizers, the content of the latter reaches more than $600 \mathrm{~g} \mathrm{t}^{-1}$.

In addition, WIR contains precious metals - $\mathrm{Au}, \mathrm{Ag}$ and $\mathrm{Pt}$, the total content of them reaches more than $40 \mathrm{~g} \mathrm{t}^{-1}$. This is followed by the rare earth elements $\mathrm{Nb}, \mathrm{Ta}, \mathrm{Zr}, \mathrm{W}$, among which cerium predominates, the content of which reaches $174 \mathrm{ppm}$. It is believed that cerium and its compounds are elements that may be of interest for inhalation therapy (Tuev and Mishlanov, 2008).

Residual chlorides and technogenic elements interfere the use of sludge as fertilizers. Residual reagents (amines, polyacrylamide, carbamides, neonol, etc.) used to enrich potash ores in the production of fertilizers Together with the sludge, they enter the places of their storage - sludge storage and become ecopollutants (Smetannikov, et. al., 2018)

Scientists and specialists from the Mining Institute of the Ural Branch Russian Academy of Sciences have developed a technology for enrichment and processing of sludge, which excludes technogenic components from their content, as well as the transformation (destruction) of residual potassium and sodium chlorides, in order to ensure the incorporation of conversed products into secondary potassium minerals and ameliorant minerals (Smetannikov, et. al, 2017). The main method was high-temperature roasting, which made it possible to remove the residual amount of organic reagents, as well as to convert sulfides into oxides, which are sorbed on matrix minerals. Thus, it is possible to use the product as complex fertilizer with trace elements owing their slow release. The resulting chloride-free product was named cinder of clay-salt sludge, hereinafter cinder. (Smetannikov, et. al., 2013, Onosov and Smetannikov, 2014). Preliminary studies carried out in 2014-2016 by scientists of the Mining Institute and Perm Agricultural Research Institute of the Ural Branch Russian Academy of Sciences have shown that the cinder effect for grain crops is approximately equal the one of traditional potassium fertilizer, provided that the doses in the active substance are also equal (Smetannikov, et. al., 2017). The essential advantages of this type of fertilizer are its complex nature (the presence of $\mathrm{K}, \mathrm{Ca}, \mathrm{Mg}$ and trace 
elements), the practical absence of chlorides, the ability to improve not only the agrochemical, but also the agrophysical properties of the soil.

Studies continued in 2018 on seed potato plots showed that complex slowrelease fertilizers were not inferior to traditional (potassium chloride) fertilizers concerning their impact to soil agrochemical properties, potato yield and quality of tubers. The content of heavy metals in potato tubers did not exceed the MPC when the full mineral fertilizer was applied at the recommended rate and was at the level of the background and control variants. Similar results were obtained for the content of heavy metals and microelements in the soil. Their content was almost the same in the treatments with cinder and potassium chloride. (Smetannikov, et. al., 2019).

Unlike other types of slow-release fertilizers, for the production of which additional technological operations are required (synthesis of organic compounds - complexones, etc.), the studied fertilizer form - the cinder contains a readymade mineral matrix. The minerals included in its composition can serve as a basis or a matrix for macro- and microelements, which allows to add an almost unlimited set of components to it (as well as plant pesticides, growth stimulants and bacterial preparations). Thus, a conceptual model for the creation of new types of mineral fertilizers with desired properties is being formed, which makes it possible to use them on different soils and climatic conditions and for crops with different requirements for mineral nutrition (Smetannikov, et. al., 2019).

In 2017 the research program for the implementation of this concept has been launched in Perm Federal Research Center of UB RAS which included the Mining Institute and PARI as divisions. The general aim is to develop the technology for obtaining complex fertilizers from waste products of $\mathrm{K}-\mathrm{Mg}$ ores and their use for seed potato and other crops. The research objectives aim in 2020 is to determine the effect of cinder as a complex ameliorant on the yield and yield quality of seed potatoes, as well as on the agrochemical indicators of sodpodzolic soil. According to agronomic practice for most of agricultural crops, PK fertilizers are applied in autumn, under the fall plowing. However, under unfavorable conditions, fertilization may be postponed to the spring before planting potato. Therefore, the auxiliary task was to determine the influence of fertilization timing on potato yield and tubers quality.

\section{MATERIAL AND METHODS}

The experimental work was fulfilled in 2018-2020 in the laboratory of technological mineralogy of Mining Institute and on the experimental farm of Perm Agricultural Research Institute situated in the suburbs of the city of Perm center of Perm Region in Russia. The experimental site is $58^{\circ} 0.615^{\prime} 0^{\prime \prime} \mathrm{N} 56^{\circ}$ 14.051' 0" E.

The climate of Perm Region is continental with long cold and snowy winters and warm short summers. The Ural Mountains play an important role in the formation of the climate, which retain the moist air masses coming from the Atlantic Ocean. The average monthly air temperature of the coldest month 
(January) is $-15.7^{\circ} \mathrm{C}$, the warmest month of July is $+18.2^{\circ} \mathrm{C}$. Average (over the last 70 years) annual air temperature $+2.4^{\circ} \mathrm{C}$, for the growing season (MaySeptember) $+13.9^{\circ} \mathrm{C}$.

The first autumn frosts are observed in 1-2 decades of September, the last spring frosts occur in the third decade of May - the first decade of June. The duration of the frost-free period on average in the region is 80-120 days. Annual precipitation in the region is $450-600 \mathrm{~mm}$, average amount for the growing season is $320-450 \mathrm{~mm}$. The formation of stable snow cover occurs at the end of the third decade of October - in the first decade of November, the height of the snow cover reaches $50-60 \mathrm{~cm}$, the melting of the snow cover occurs in the third decade of April.

The objects of the study were potato plants of the variety "Nevsky" and sod-podzolic heavy loam soil (Umbric Albeluvisols Abruptic) with following agrochemical parameters: $\mathrm{pH}_{\mathrm{KCl}}-5.4$, content of mineral $\mathrm{N}-30 \mathrm{mg} \mathrm{kg}{ }^{-1}, \mathrm{P}_{2} \mathrm{O}_{5}-$ $410 \mathrm{mg} \mathrm{kg}^{-1}, \mathrm{~K}_{2} \mathrm{O}-100 \mathrm{mg} \mathrm{kg}-1, \mathrm{Ca}-11,3 \mathrm{mmol} 100 \mathrm{~g}^{-1}, \mathrm{Mg}-3,3 \mathrm{mmol} 100 \mathrm{~g}$ ${ }^{1}$ (2018, before experiment foundation).

The subjects - were the traditional potassium fertilizer - potassium chloride $(\mathrm{KCl})$ and cinder. The technology of obtaining cinder from clay-salt sludge includes following stages: hydrocycloning, filtration, granulation, drying, high temperature firing and protected by the patent RF № 2497961 from 10.11.2013. The used cinder was obtained at a firing temperature of $900^{\circ} \mathrm{C}$, the optimum temperature for removing the residual amount of organic reagents and chlorine as well as to convert sulfides into oxides (Onosov and Smetannikov, 2014).

The main chemical compounds in cinder are following (mass percent): $\mathrm{SiO}_{2}-29,34 ; \mathrm{Al}_{2} \mathrm{O}_{3}-6,03 ; \mathrm{Fe}_{2} \mathrm{O}_{3}-6,48 ; \mathrm{CaO}-13,9 ; \mathrm{MgO}-12,44 ; \mathrm{Na}_{2} \mathrm{O}$ - 5,18; $\mathrm{K}_{2} \mathrm{O}-4,84 ; \mathrm{P}_{2} \mathrm{O}_{5}-1,38 ; \mathrm{S}-0,19$; trace elements content (mg kg $\left.{ }^{-1}\right)$ : $\mathrm{Ni}-320,8$; $\mathrm{Cu}-156,5 ; \mathrm{Zn}-153,2$; As - 20,1; Mo- 3,22.

Analyses were fulfilled in Analytical Certificate Testing Center (Moscow) on atomic emission spectrometer with inductive-chemical plasma Optima-4300 DV and mass spectrometer with inductive-structure plasma Elan-6100.

The study of direct action took place in 2019, aftereffects - in 2020. The applied fertilizers: 1) NP commercial fertilizer mixture with $\mathrm{N}$ content 22.43 percent , $\mathrm{P}_{2} \mathrm{O}_{5}-21.12 \%$, 2) Potassium chloride $-\mathrm{K}_{2} \mathrm{O} 59.29$ percent 3) Cinder (C3) - $\mathrm{K}_{2} \mathrm{O} 4,84$ percent. Fertilizers rates (active ingredient): $\mathrm{N}_{90} \mathrm{P}_{90}$ and $\mathrm{N}_{90} \mathrm{P}_{90} \mathrm{~K}_{90}$. Fertilization timing in 2018-2019 - autumn (basic application-BA and spring (pre-planting application-PA). No fertilizers were used in 2020. The cultural practice is usual for potato in Perm Region excluding the studied elements.

Experimental scheme

1.Control (no fertilizers);

2.NP- background (pre-planting application)

3. Background $+\mathrm{KCl}$ (basic application) 
4.Background + C3 (BA)

5.Background $+\mathrm{KCl}(\mathrm{PA})$

6.Background + C3 (PA)

Treatment placing is systematic, each treatment has three replications on field area. Plot area $32.8 \mathrm{~m}^{2}$.

Soil and plant chemical analyses were fulfilled in analytical laboratory of Perm Agricultural Research Institute, according valid national standards. The obtained data were statistically processed by analysis of variance (using least significant difference - LSD).

\section{RESULTS AND DISCUSSION}

The growing season of 2019 was characterized by slightly elevated temperature and moisture deficit in the first half, by sharp heat deficiency and excessive rainfall - in the second. The average season temperature was $+13.5^{\circ} \mathrm{C}$, which is $0.4^{\circ} \mathrm{C}$, lower than multiyear average, precipitation sum was $535 \mathrm{~mm}$ (160 percent from multiyear average $-335 \mathrm{~mm}$ ). Extremely wet and cold weather conditions were in August, rainfall amount was $233 \mathrm{~mm}$ (306 percent). The conditions for tuberization process and harvesting were unfavorable.

The growing season of 2020 was drier and hotter. The average season temperature was $+14.8^{\circ} \mathrm{C}$, precipitation sum was $332 \mathrm{~mm}$ (99 percent). In July, when the budding and flowering phases were observed on the plants, hot weather was noted, which, with a significant, almost 2 times, deficiency in rainfall amount, had a significant negative effect on potato productivity. The influence of cinder and traditional mineral fertilizers application (2019) on and their aftereffect (2020) is presented in the Table 1.

Table 1. Cinder and traditional mineral fertilizers impact on potato yield (Nevsky variety)

\begin{tabular}{|c|c|c|c|c|c|c|}
\hline \multirow{3}{*}{ Treatments } & \multicolumn{3}{|c|}{2019} & \multicolumn{3}{|c|}{2020} \\
\hline & \multirow[b]{2}{*}{$\begin{array}{l}\text { Yield, } \\
\mathrm{t} \mathrm{ha}^{-1}\end{array}$} & \multicolumn{2}{|c|}{ Supplements } & \multirow[b]{2}{*}{$\begin{array}{l}\text { Yield, } \\
\text { ha }^{-1}\end{array}$} & \multicolumn{2}{|c|}{ Supplements } \\
\hline & & $\begin{array}{c}\text { against } \\
\text { control, } \\
\text { t ha }^{-1}\end{array}$ & $\begin{array}{c}\text { to the } \\
\text { background, } \\
\text { t ha }^{-1}\end{array}$ & & $\begin{array}{c}\text { against control, } \\
\mathrm{t} \mathrm{ha}^{-1}\end{array}$ & $\begin{array}{c}\text { to the } \\
\text { background, } \\
\text { t ha }^{-1}\end{array}$ \\
\hline $\begin{array}{l}\text { Control } \\
\text { (no fertilizers) }\end{array}$ & 36,2 & - & - & 8,59 & - & - \\
\hline NP- background & 43,8 & 7,6 & - & 12,06 & 3,47 & - \\
\hline $\mathrm{NP}+\mathrm{KCl}(\mathrm{BA})$ & 44,9 & 8,7 & 1,1 & 13,77 & 5,18 & 1,71 \\
\hline $\mathrm{NP}+\mathrm{C} 3(\mathrm{BA})$ & 37,8 & 1,6 & $-6,0$ & 9,13 & 0,54 & $-2,93$ \\
\hline $\mathrm{NP}+\mathrm{KCl}(\mathrm{PA})$ & 47,1 & 10,9 & 3,3 & 13,32 & 4,73 & 1,25 \\
\hline NP + C3 (PA) & 46,0 & 9,8 & 2,2 & 10,18 & 1,59 & $-1,89$ \\
\hline $\mathrm{LSD}_{05}$ & & 6 & & & 2,21 & \\
\hline
\end{tabular}

The overall yield in 2019 (Table 1) was significantly higher compared with 2020 , because of fertilizer effect and weather conditions. The growing season of 2019 was characterized by excessive amount of precipitation, and 2020 - by dry weather conditions. All studied treatments with fertilization provided an increase in yield compared to the control, but the magnitude of the increase varied 
significantly among treatments and by years of observation as well. The supplements ranged from 2.9 to $12 \mathrm{t} / \mathrm{ha}^{-1}$.

The only treatment with fertilizers use (cinder in the fall) did not provide a significant increase in potato yield. The increase was within the experimental error. The largest increments from 11 to $12 \mathrm{t}^{-1}$ were provided by the spring application of potassium fertilizers on the background of NP. The effect of cinder was approximately equal to traditional potassium chloride. It should be noted that the increase in yield was obtained mainly due to nitrogen and phosphorus fertilizers. The autumn application of potassium fertilizers did not provide an increase in yield compared to the background. Perhaps, it may be connected with potassium leaching in the extremely rainy autumn in 2018 .

The results of 2019 can be explained by unfavorable weather conditions during the tuberization period, when the temperature was below optimal, and precipitation amount was significantly higher compared with multiyear average. It is the very period when potassium is most needed for potato, which absorption into plants under these conditions is difficult. This is confirmed by the results of research by Mikhailova et. al., (2013), who argues that in a year with excessive moisture, an increase in yield can be obtained only due to nitrogen and phosphorus. Some authors (Pukhalskaya et al., 2009, Grzebisz et al., 2020) considered that potassium improves plant nutrition with nitrogen, while not independently causing an increase of yield.

In 2020, the effectiveness of fertilizers application (aftereffect) was low. The use of cinder did not provide an increase in yield against the control, and compared to the background there was a slight decrease in the supplements value. The observed deviations were within the experimental error or close in magnitude to $\mathrm{LSD}_{05}$.

Table 2. Influence of the action (2019) and aftereffect (2020) of cinder on the yield structure of potato.

\begin{tabular}{|c|c|c|c|c|c|c|c|c|}
\hline \multirow[t]{2}{*}{ Treatments } & \multicolumn{2}{|c|}{$\begin{array}{c}\text { Mass of tubers, } \\
\text { g per plant }\end{array}$} & \multicolumn{2}{|c|}{$\begin{array}{c}\text { Number of tubers } \\
\text { per plant }\end{array}$} & \multicolumn{2}{|c|}{$\begin{array}{l}\text { Average tuber } \\
\text { mass, } g\end{array}$} & \multicolumn{2}{|c|}{$\begin{array}{l}\text { Seed fraction, } \\
\text { percent }\end{array}$} \\
\hline & 2019 & 2020 & 2019 & 2020 & 2019 & 2020 & 2019 & 2020 \\
\hline $\begin{array}{l}\text { Control } \\
\text { (no fertilizers) }\end{array}$ & 1074,0 & 301,6 & 19,2 & 11,8 & 56,3 & 25,4 & 80,3 & 69,8 \\
\hline NP- background & 1200,7 & 444,9 & 17,5 & 14,5 & 69,0 & 33,6 & 70,5 & 68,7 \\
\hline $\mathrm{NP}+\mathrm{KCl}(\mathrm{BA})$ & 1276,0 & 486,3 & 19,2 & 8,2 & 66,4 & 37,9 & 64,4 & 61,5 \\
\hline $\mathrm{NP}+\mathrm{C} 3(\mathrm{BA})$ & 1120,7 & 318,5 & 18,3 & 13,5 & 61,5 & 33,5 & 76,4 & 59,8 \\
\hline $\mathrm{NP}+\mathrm{KCl}(\mathrm{PA})$ & 1334,7 & 411,6 & 19,3 & 14,0 & 69,0 & 30,1 & 68,1 & 55,5 \\
\hline $\mathrm{NP}+\mathrm{C} 3(\mathrm{PA})$ & 1284,9 & 317,4 & 19,3 & 8,4 & 66,9 & 37,1 & 70,4 & 72,6 \\
\hline $\mathrm{LSD}_{05}$ & $\mathrm{~F}_{\phi}<\mathrm{F}_{\mathrm{T}}$ & 88,1 & $\mathrm{~F}_{\phi}<\mathrm{F}_{\mathrm{T}}$ & 3,6 & 9,6 & 5,9 & 11,8 & 10,7 \\
\hline
\end{tabular}

The low potato yield in 2020 is confirmed by data on the structure of potato yield (Table 2). The mass of tubers from one plant this year was on average 3-3.5 times less compared with 2019. In 2019, the mass of tubers varied within 1074-1334 g per plant without significant differences between treatments 
(Ff < Ft). In 2020, the use of NP fertilizers and complete mineral fertilization in the traditional version with potassium chloride provided a significant increase of tuber mass from one plant, due to increase both the number of tubers and the average mass of one tuber. The smallest mass of tubers was obtained in treatments with cinder application and in the control treatment - 301-318 g per plant.

In all studied treatments with the use of fertilizers, the average mass of the tuber was significantly higher compared with the control, without significant differences depending on the types and combinations of fertilizers. In general, the yield raise was due to an increase in the weight of one tuber, the number of tubers per plant remained approximately at the same level with the control. It may be considered the variety peculiarity. The same results were obtained by other researches (López-Martín, et al., 2018). The content of the seed fraction in the yield slightly decreased in comparison with the control because of the increase of large tubers number. In the treatment without fertilizers, the share of the seed fraction reached 80 percent in 2019 and was about 70 percent in 2020, which is, respectively, high and satisfactory results for seed potato plantings (Torikov et. al., 2011, Anisimov and Zebrin, 2018, Zhevora, et. al., 2019) In the treatments with fertilizers seed fraction content varied from 55 to 76 percent, what was, as a rule, within the experimental error.

Table 3. Influence of the action (2019) and aftereffect (2020) of cinder on the yield quality parameters of potato.

\begin{tabular}{lccccc|cc}
\hline \multirow{2}{*}{ Treatments } & \multicolumn{2}{c|}{ Dry matter, \% } & \multicolumn{2}{c|}{ Nitrates, $\mathrm{mg} \mathrm{kg}^{-1}$} & \multicolumn{2}{c}{ Starch, \% } \\
\cline { 2 - 7 } Control & 2019 & 2020 & 2019 & 2020 & 2019 & 2020 \\
(no fertilizers) & 15,39 & 19,80 & 18,9 & 93,75 & 10,6 & 12,88 \\
NP- background & 16,61 & 18,90 & 18,1 & 82,10 & 11,1 & 12,04 \\
NP + KCl (BA) & 16,30 & 20,83 & 17,7 & 77,40 & 10,7 & 13,90 \\
NP + C3 (BA) & 14,85 & 20,41 & 19,1 & 65,50 & 10,7 & 12,88 \\
NP + KCl (PA) & 15,33 & 21,19 & 19,4 & 76,22 & 9,8 & 13,84 \\
NP + C3 (PA) & 14,43 & 19,29 & 19,2 & 91,20 & 9,5 & 12,98 \\
LSD $_{05}$ & 0,94 & 0,58 & $\mathrm{~F}_{\phi}<\mathrm{F}_{\mathrm{T}}$ & 11,34 & 0,6 & 0,41 \\
\hline
\end{tabular}

The use of mineral fertilizers types in this experiment did not have a significant effect on the quality parameters of potato tubers yield (Table 3 ). The dry matter content varied according to the within $1-1.2 \%$ in 2019 , which slightly exceeds the value of HCP05 - 0.94. Such an excess does not play a significant role in practical terms. The use of cinder reduced the percentage of dry matter in potato tubers compared to NP background, but this trend was not confirmed in 2020. It should be noted that in 2020 the dry matter content in potato tubers was on average $4-5 \%$ higher compared to 2019 , which is explained by the low potato yield this year because of dry weather conditions during the period of crop formation. This trend was noted by other researchers (Neronova and Golubeva, 2012). 
The nitrate content in 2019 in all the studied treatments was practically the same, the differences were within the experimental error, the starch content also did not have significant deviations from the control. The similar situation with the starch content was noted in 2020. Conflicting data have been obtained that year for nitrates content, so additional study is required. In the variants with NP application the content of nitrates significantly decreased, which contradicts the data of other research works (Pukhalskaya et. al.,2009, Mikhailova et. al., 2013). At the same time, the content of nitrates in 2020 was 4-5 times higher compared with the corresponding indicators in 2019, which can be explained by the low yield of potato this year connected with a lack of moisture.

The starch content decreased in treatments with spring application of both potassium fertilizers by one percent approximately compared with the control (2019), but this trend did not confirm next year. The slight aftereffect of $\mathrm{KCl}$ use was noted. In our previous research the quality of potato tubers significantly decreased, but at higher doses of fertilizers $-\mathrm{N}_{150} \mathrm{P}_{150} \mathrm{~K}_{150}$ (Korlyakov, et. al., 2018).

An important task in improving the technology of potato production is to preserve the harvest. It is known that cultivation technology, as well as weather conditions, can affect the safety of tubers in different ways. Therefore, some of the tubers were laid according to the treatments for storage in September 2019, after harvesting. In May 2020, the weight loss was taken into account in comparison with the weight before storing, and the quality indicators of potato after storage were studied (Table 4).

Table 4. Impact of fertilizers on preservation degree of potato yield and its quality parameters (2020).

\begin{tabular}{|c|c|c|c|c|c|}
\hline \multirow[b]{2}{*}{ Treatments } & \multicolumn{2}{|c|}{ Dry matter, percent } & \multicolumn{2}{|c|}{ Starch, percent } & \multirow{2}{*}{$\begin{array}{l}\text { Percent of the } \\
\text { original sample } \\
\text { weight, } \\
\text { preserved by } \\
\text { planting time }\end{array}$} \\
\hline & $\begin{array}{c}\text { in } \\
\text { spring }\end{array}$ & $\begin{array}{l}\text { percent to } \\
\text { autumn } \\
\text { indicators }\end{array}$ & $\begin{array}{c}\text { in } \\
\text { spring }\end{array}$ & $\begin{array}{l}\text { percent to } \\
\text { autumn } \\
\text { indicators }\end{array}$ & \\
\hline $\begin{array}{l}\text { Control } \\
\text { (no fertilizers) }\end{array}$ & 15,89 & 103,2 & 12,91 & 121,8 & 60,1 \\
\hline NP - background & 14,80 & 89,1 & 12,56 & 113,2 & 65,0 \\
\hline $\mathrm{NP}+\mathrm{KCl}(\mathrm{BA})$ & 14,39 & 88,3 & 11,75 & 109,8 & 67,5 \\
\hline NP + C3 (BA) & 13,27 & 89,4 & 11,60 & 108,4 & 58,7 \\
\hline $\mathrm{NP}+\mathrm{KCl}(\mathrm{PA})$ & 14,66 & 95,6 & 12,52 & 127,8 & 63,5 \\
\hline NP + C3 (PA) & 13,44 & 93,1 & 12,44 & 130,9 & 68,0 \\
\hline $\mathrm{LSD}_{05}$ & 1,1 & & 0,33 & & $\mathrm{FT}_{\mathrm{T}}>\mathrm{F} \phi$ \\
\hline
\end{tabular}

In the treatment without fertilizers, there was a slight increase in the dry matter content - by $3.2 \%$, but the difference was insignificant, most likely within the observation error. Therefore, it can be assumed that in this variant the dry matter content during the storage period was stable, without significant changes. 
The dry matter content decreased in spring in all studied variants with fertilizers compared with autumn indicators. The negative effect of the use of mineral fertilizers on the dry matter content preservation of potato during storage was also noted by Sabirov and Sabirova, 2012.

The picture with the content and preservation of starch was not so obvious: in the variants with autumn application of potassium fertilizers ( $\mathrm{KCl}$ and cinder), the starch content was significantly lower compared with the control - by more than one percent on average, in the treatments with the spring application of potassium fertilizers it was slightly inferior to the control. At the same time, there was no decrease in the starch content during the storage period; on the contrary, it increased in all variants of the experiment. The most significant growth by 20-30 percent was observed in treatments with a higher initial starch content.

The total mass of the samples during storage decreased by 32-42 percent, with insignificant variation in the experimental variants, the difference between the variants was within the experimental error. Thus, the introduction of various types of fertilizers did not have a significant effect on the preservation of potato during storage. The tendency of starch content raising at the end of the storage period was found, this trend needs to be investigated in further research.

Table 5. Impact of mineral fertilizers application on agrochemical parameters of sod-podzolic soil.

\begin{tabular}{|c|c|c|c|c|c|c|c|c|c|c|c|c|}
\hline \multirow{3}{*}{ Treatments } & \multirow{2}{*}{\multicolumn{2}{|c|}{$\mathrm{pH}_{\mathrm{KCl}}$}} & & $\mathrm{Ca}$ & \multicolumn{2}{|c|}{$\mathrm{Mg}$} & \multicolumn{2}{|c|}{ Nmin } & \multicolumn{2}{|c|}{$\mathrm{P}_{2} \mathrm{O}_{5}$} & \multicolumn{2}{|c|}{$\mathrm{K}_{2} \mathrm{O}$} \\
\hline & & & \multicolumn{4}{|c|}{$\mathrm{mmol} 100 \mathrm{~g}^{-1}$} & \multicolumn{6}{|c|}{$\mathrm{mg} \mathrm{kg}^{-1}$} \\
\hline & 2019 & 2020 & 2019 & 2020 & 2019 & 2020 & 2019 & 2020 & 2019 & 2020 & 2019 & 2020 \\
\hline $\begin{array}{l}\text { Control } \\
\text { no fertilizers) }\end{array}$ & 4,74 & 4,63 & 10,7 & 11,3 & 3,6 & 2,1 & 26 & 21 & 362 & 294 & 116 & 115 \\
\hline NP - background & 4,52 & 4,66 & 12,1 & 11,6 & 3,3 & 1,7 & 34 & 16 & 432 & 277 & 108 & 107 \\
\hline $\mathrm{NP}+$ & 4,57 & 4,66 & 11,6 & 10,5 & 3,5 & 2, & 30 & 17 & 376 & 327 & 143 & 113 \\
\hline $\mathrm{NP}+$ & 4,79 & 4,83 & 11,1 & 10,6 & 4,0 & 1,3 & 30 & 17 & 384 & 365 & 149 & 183 \\
\hline $\mathrm{NP}+$ & 4,54 & 4,58 & 10,6 & 11 & 4,3 & 2, & 37 & 18 & 348 & 213 & 102 & 103 \\
\hline $\mathrm{NP}+\mathrm{C} 3$ & 4,67 & 4,65 & 10,6 & 11,4 & 4,1 & 2,1 & 39 & 20 & 316 & 230 & 138 & 152 \\
\hline $\operatorname{LSD}_{05}$ & 0,15 & 0,14 & 0,86 & $\mathrm{~F}_{\phi}<\mathrm{F}_{1}$ & 0,79 & $\mathrm{~F}_{\phi}<\mathrm{F}_{1}$ & 5 & $\mathrm{~F}_{\phi}<\mathrm{F}_{\mathrm{T}}$ & 85 & 51 & 33 & 12 \\
\hline
\end{tabular}

Table 5 presents the data on fertilizers application effect on the agrochemical parameters of the soil. In both years of research, the value of soil acidity $(\mathrm{pH})$ did not change significantly and averaged 4.7. There was one exception in the treatment with autumn cinder application, where in 2020 the $\mathrm{pH}$ value was 4.83 , which is significantly higher than the $\mathrm{pH}$ value in the control 4.63. The cinder contains compounds of $\mathrm{Ca}$ and $\mathrm{Mg}$, which, when applied in autumn, can pass to the spring in forms accessible to plants and be assimilated during the subsequent growing season. This, however, is not confirmed by the data on the content of $\mathrm{Ca}$ and $\mathrm{Mg}$ in the soil, which did not differ significantly from the control variant. In studies related to soil fertility indicators, it is difficult to make any definite conclusions based on two years of research, longer observations are required. 
The content of mineral nitrogen in 2019 did not change significantly under the influence of the basic application of full mineral fertilizer (NPK), but increased on the NP background and in treatments with spring pre-planting application, which was quite expected. In 2020 the difference between treatments was within experimental error $\left(\mathrm{F}_{\phi}<\mathrm{F}_{\mathrm{T}}\right)$. Nitrogen compounds are characterized by increased solubility in soil and are quickly absorbed by plants, therefore, the aftereffect of $\mathrm{N}$ fertilizers for the next year was not observed.

The $\mathrm{P}_{2} \mathrm{O}_{5}$ content slightly increased in 2019 on the NP background and reached the maximum value in the experiment $-432 \mathrm{mg} \mathrm{per} \mathrm{kg}^{-1}$ of soil, which is higher compared with the control by $70 \mathrm{mg}$, but within the experimental error. In the other treatments, the difference was even less significant. The same picture was observed in 2020.

The content of $\mathrm{K}_{2} \mathrm{O}$ in treatments with traditional mineral fertilizers did not differ significantly from the control variant. The use of cinder, both in spring and autumn, led to a noticeable increase in $\mathrm{K}_{2} \mathrm{O}$ in the soil. The raising of $\mathrm{K}_{2} \mathrm{O}$ content compared with the control after autumn application was equal to LSD 05 value (33 mg) in 2019 and reached $183 \mathrm{mg}$ in 2020 (maximum in the experiment). In the treatment with spring application the difference was insignificant (22 mg) in 2019, but next year was reached $37 \mathrm{mg}$ (LSD 05 value 12 $\mathrm{mg}$ ). The total $\mathrm{K}_{2} \mathrm{O}$ content was higher in 2020 compared with 2019 for both these treatments. This trend can be explained by the slow release of potassium from poorly soluble compounds in the cinder composition.

\section{CONCLUSIONS}

Preliminary studies on potato have confirmed the positioning of the cinder as a complex slow-release fertilizer, containing in its composition trace elements $\mathrm{Cu}, \mathrm{Zn}$ and others, as well as minerals - ameliorants ( $\mathrm{Ca}$ and $\mathrm{Mg}$ compounds).

The direct effect of unconventional mineral fertilizer (cinder) with its preplanting application was not inferior to traditional potassium chloride fertilization (yield in $2019-46.0$ and $47.1 \mathrm{t}^{-1}$ ha, respectively). The use of cinder did not have a significant effect on the quality indicators of potato tubers both directly in the year of fertilization and after the storage period. Cinder, in contrast to the standard $\mathrm{KCl}$ fertilizer, had a positive effect on the content of exchangeable potassium in the soil. Research with unconventional mineral fertilizers based on $\mathrm{K}-\mathrm{Mg}$ ore processing wastes should be continued with an emphasis on the study of long-term action as a complex ameliorant.

\section{ACKNOWLEDGEMENTS}

The research work was fulfilled and given paper was prepared with the financial support and as part of the scientific program "The development of potato selection and seed production in Russian Federation".

\section{REFERENCES}

Anisimov B.V., Zebrin S.N. (2018): Нормативное регулирование коммерческого качества семенного картофеля. Regulatory regulation of the commercial quality of seed potato. Potato system, 4: 36-41 (in Russian with English abstract). 
Bachurin B.A., Smetannikov A.F., Khokhryakova E.S. (2014): Эколого-геохимическая оценка продуктов переработки глинисто-солевых шламов калийного производства. Ecological and geochemical evaluation of products of processing clay-salt sludge of potash production. Problems of modern science and education, 6: (available at www.science-education.ru.120-15442 - in Russian with English abstract)

FAOSTAT Agriculture (2015): FAO statistical database. (available at www.fao.org.corp.statistics.en).

Grzebisz, W., Szczepaniak, W., \& Bocianowski, J. (2020): Potassium fertilization as a driver of sustainable management of nitrogen in potato (Solanum tuberosum L.). Field Crops Research, 254, 1 September, 2020: 107824.

Gurbanova Z.R., Gumbatov M.O., Gurbanov E.A. (2017): Получение гранулированного фосфорного удобрения, обогащенного микроэлементами. Obtaining granular phosphorus fertilizer enriched with trace elements. Problems of modern science and education. 88(6): 17-19 (in Russian with English abstract).

Hu, P., Zhang, Y., Wang, X., Zhou, Y., Tong, W., Luan, X., Ma, X., Zhou, F., Chu, P.K., Zhao P. (2018) : K2MgSi3O8 in slow-release mineral fertilizer prepared by sintering of by-product of red mud-based flocculant. Environmental Eng. Sci., 35 (8): 829-835.

Korlyakov K.N., Kosolapova A.I., Fomin D.S., Yamaltdinova V.R., Smetannikov A.F. (2018): Отзывчивость картофеля сорта Невский на возрастающие дозы минеральных удобрений. Responsiveness of Nevsky potatoes to increasing doses of mineral fertilizers. In: Proceedings of the international scientific-practical conference Theoretical Foundations and Applied Research in Potato Breeding and Seed Production. Institute of Cytology and Genetics SB RAS, Novosibirsk: 23. DOI 10.18699 / Potato-2018-19 GI - 1 (in Russian with English abstract).

Korshunov A.V. (2003): Технология возделывания картофеля. Technologies of potato cultivation. In: Potato of Russia, pp 256-268. Moscow. 987 pp (in Russian).

Krutko N.P., Shevchuk V.V. (2011): Совершенствование технологии производства гранулированных калийных удобрений и повышение их качества. Improving the production technology of granular potash fertilizers and improving their quality. Mine of the Future. 4 (8): 12-14 (in Russian with English abstract).

Li, J., Zhuang, X., Font, O., Moreno, N., Vallejo, V.R., Querol, X., Tobias, A. (2014): Synthesis of merlinoite from Chinese coal fly ashes and its potential utilization as slow release K-fertilizer. Journal of Hazardous Materials, 265: 242-252.

López-Martín J.J, Morales-Corts M.R., Pérez-Sánchez R., Gómez-Sánchez M.A. (2018): Efficiency of garden waste compost teas on potato growth and its suppressiveness against rhizoctonia. Agriculture \& Forestry, 64 (4): 7-14, DOI: 10.17707/AgricultForest.64.4.01

Mikhailova L.A., Alyoshin M.A., Alyoshina D.V. (2013):): Влияние условий минерального питания на продуктивность и качество картофеля при возделывании на дерново-подзолистой тяжело-суглинистой почве. Influence of conditions of mineral nutrition on the productivity and quality of potatoes when cultivated on sod-podzolic heavy loamy soil. Perm Agrarian Bulletin, 1 (1): 9-14 (in Russian with English abstract). 
Neronova E. E., Golubeva N. I. (2012): Продуктивность картофеля при использовании отдельных элементов программы минерального питания. Potato productivity when using individual elements of the mineral nutrition program. Bulletin of the RSATU, Ryazan 14 (2): 73-76 (in Russian with English abstract).

Onosov D.V., Smetannikov A.F. (2014): Разработка технологии комплексной утилизации отходов переработки калийно-магниевых руд. Development of a technology for the integrated utilization of potash and magnesium ore processing wastes. In: Proceedings of the international scientific-practical conference Problems of safety and efficiency of development of georesources in modern conditions. MI UB RAS, Perm: 167-171 (in Russian with English abstract).

Pukhalskaya N.V. Sychev V.G. Sobachkin A.A., Pavlova N.I. (2009): Особенности калийного питания

сельскохозяйственных растений в оптимальных и неблагоприятных условиях. Peculiarities of potassium nutrition of agricultural plants in optimal and unfavorable conditions. Moscow, Pryanishnikov Institue Agrochemistry: 58 pp. (in Russian).

Rajičić V., Milivojević J., Popović V., Branković S., Đurić N., Perišić V., Terzić D. (2019): Winter wheat yield and quality depending on the level of nitrogen, phosphorus and potassium fertilization. Agriculture \& Forestry, 65 (2): 79-88, DOI: 10.17707/AgricultForest.65.2.06

Rajičić V., Terzić, D., Perišić, V., Dugalić, M., Madić, M., Dugalić, G., Ljubičić, N. (2020): Impact of long-term fertilization on yield in wheat grown on soil type vertisol. Agriculture and Forestry, 66 (3): 127-138. DOI: 10.17707/AgricultForest.66.3.11

Ruthrof, K.X., Steel, E., Misra, S., McComb, J., O'Hara, G., Hardy, G.E.S.J., Howieson, J. (2018): Transitioning from phosphate mining to agriculture: Responses to urea and slow release fertilizers for Sorghum bicolor. Science of the Total Environment, 625: $1-7$.

Sabirov R.A., Sabirova T.P. (2012): Влияние содержания крахмала в семенных клубнях на продуктивность среднераннего картофеля Невский. Influence of starch content in seed tubers on the productivity of medium early potato variety "Nevsky". Bulletin of the APK of the Upper Volga, 2 (18): 38-40 (in Russian with English abstract).

Sharipova, D.S., Aitbayev, T.E., Tazhibayev, T.S., Nacheva, E.K (2016): The impact of new and improved elements of agricultural technologies on potato productivity in the south-east of Kazakhstan. Biosciences Biotechnology Research Asia. 13 (2): 1031-1036.

Smetannikov A.F., Onosov D.V., Sinegribov V.A., Kosolapova A.I., Novikov P.Yu (2013): Способ переработки калийных руд. A method of processing potash waste, RF patent № 2497961. Application 2012142039. Registered on November 10. (in Russian).

Smetannikov A.F., Kosolapova A.I., Mitrofanova E.M., Bachurin B.A., Onosov D.V., Fomin D.S., Yamaltdinova V.R., Shishkov D.G., Onosova E.F.(2017): Результаты испытаний отходов переработки калийно-магниевых руд в качестве удобрения пролонгированного действия. Test results of waste potashmagnesium ore processing as fertilizers of prolonged action. Bulletin of the PSC, Perm. 4: 58-63(in Russian with English abstract). 
Smetannikov A.F., Kosolapova A.I., Bachurin B.A., Onosov D.V., Fomin D.S., Yamaltdinova V.R., Shishkov D.G., Onosova E.F. (2018): Разработка методологического подхода в применении комплексных удобрений пролонгированного действия для зерновых культур, многолетних трав и картофеля. Development of a methodological approach to the application of complex fertilizers of prolonged action for crops, perennial herbs and potatoes. In: Scientific Readings in Memory of P.N. Chirvinsky. Perm, Vol 21:415-423 (in Russian with English abstract).

Smetannikov A. F., Kosolapova A. I., Korlyakov K.N.Onosov D.V., Fomin D.S., Ymaltdinova V. R., Shishkov D. G., Onosova E. F.(2019): Концепция использования комплексных удобрений пролонгированного действия на основе отходов переработки калийно-магниевых руд, как новой парадигмы в восстановлении (улучшении) плодородия почв и семеноводстве картофеля. Concept of use of comprehensive fertilizers of long-term action on the basis of waste processing of potassium-magnesium ore as a new paradigm in improving soil fertility. Dokuchaev Soil Bulletin.100: 133-158, DOI; 10. 19047/0136-16942019-100-133-158 (in Russian with English abstract).

Torikov V.E., Kotikov M.V., Bogomaz M.A., Yaryshkin E.P. (2011): Продуктивность картофеля и структура урожая клубней в зависимости от системы удобрений. Productivity and structure of tubers yield depending on fertilization systems. Agroconsultant Bryansk State Agrarian University. 3:22-26 (in Ryssian).

Tuev A.V., Mishlanov V.Yu. (2008): Хронические бронхо-деструктивные заболевания и кардиоваскулярная система. Chronic broncho-obstructive diseases and the cardiovascular system. Perm. 184 pp. (in Russian with English abstract).

Yamaltdinova V.R., Fomin D.S., Shishkov D.G. (2019): Влияние длительного применения удобрений на азотный режим дерново-подзолистой почвы и урожайность картофеля (Solanum tuberosum L.) The influence of long-term use of fertilizers on the nitrogen regime of sod-podzolic soil and the yield of potato (Solanum tuberosum L.) Problems of agrochemistry and ecology. 1: 10-13. (in Russian with English abstract).

Zhevora S.V. Chugunov V.S., Shatilova O.N., Anisimov B.V (2017): Текущее состояние и прогноз производства картоеля в Российской Федерации. Current state and forecast of potato production in Russian Federation), Zhevora S.V., In: Proceedings of the international scientific-practical conference Innovative technologies of selection and seed production of potatoes. Moscow: 29-30 (in Russian with English abstract).

Zhevora S.V., Anisimov B.V., Simakov E.A., Oves E.V., Zebrin S.N. (2019): Картофель: проблемы и перспективы. Potato: problems and prospects. Potato and vegetables. 7: 2-7 (in Russian with English abstract). 